\title{
Between policy and science: research councils' responsiveness in Austria, Norway and Switzerland
}

\author{
Stig Slipersæter, Benedetto Lepori and Michael Dinges
}

\begin{abstract}
This paper investigates the developments of research councils in Austria, Norway and Switzerland, and analyses their responsiveness to government and science. By use of various data sources and indicators, our results suggest that councils are sometimes more responsive to the beneficiaries' interests (science) than to policy-makers, but are more responsive to government policies when under stronger government control. Patterns of responsiveness tend to be stable through time despite important changes in national contexts and the changing roles and organisation of research councils. These findings have interesting theoretical consequences about responsiveness and independence
\end{abstract}

$\mathrm{R}$ ESEARCH COUNCILS have been the preferred way of institutionalising 'the second stream' of research funding in most industrialised countries. Both researchers and research institutions are perceiving council funding for research projects allocated through research grants, programmes and projects as increasingly important (Geuna, 2001; Geuna and Martin, 2003). Instruments and criteria are co-decisive for the selection of research topics, for researchers' adaptive strategies and their ability to perform high quality research (Laudel, 2006), but also because general government appropriations often are tied up with the coverage of running costs, leaving the institutions with little freedom. Funding from intermediaries such as research councils might thus be the only way to make possible new research initiatives and thereby scientific development.

Stig Slipersæter is NIFU STEP, Wergelandsv. 7, N-0167 Oslo, Norway; Email: stig.slipersater@nifustep.no; Tel: +47 225951 81; Fax: +47 225951 01. Benedetto Lepori is at Università della Svizzera italiana and Observatoire des Sciences et Techniques, via Lambertenghi 10a, 6904 Lugano; Email: blepori@unisi.ch; Tel: +41 5866646 14; Fax: +41 586664619. Michael Dinges is at the Joanneum Research Forschungsgesellschaft mbH, Institute of Technology and Regional Policy, Haus der Forschung, Sensengasse 1, 1090 Wien, Austria; Email: michael.dinges@joanneum.at; Tel: +43 15817520 2813; Fax: +43158175202820.
Research councils are in many ways semiindependent agencies operating at arm's length from government and can often be closely linked to the research community. Their loyalty can thus be bidirectional, and the councils might have to balance between the interests of policy-makers and scientists. Our main concern is to analyse how research councils act as intermediaries influenced by national research policies on one hand and the research community on the other. By comparing research councils in Austria, Norway and Switzerland, we will shed light on the importance of the councils' embeddedness in national contexts and history for how they play their roles.

We first introduce the research questions we are posing. Then we discuss the theoretical framework underlying our understanding of research councils' actions and responses to policy, before we lay out the chosen analytical model and methodology. We then present the councils and give empirical evidence on the developments along the selected variables. Finally, we discuss the findings.

\section{Research questions}

Research councils play a crucial role in scientific development and in science policy in most industrial countries and are often assigned the task of allocating 
Stig Slipersæter has been a senior researcher at NIFU STEP since 1997. He graduated from the University of Oslo with a degree in sociology of science. Research interests include S\&T indicators in the domains of higher-education institutions, public and private research institutes, and human resources. He has also been analysing research policy and organisation of the research system, organisation of research institutes and higher-education institutions, and the internationalisation of research.

Benedetto Lepori obtained his degree in mathematical physics at the University of Rome in 1988 and a PhD in communication sciences at the University of Lugano in 2004 with a thesis on Swiss research policy. Since 1997, he has been responsible of the research office of the Università della Svizzera Italiana. His research interests cover Swiss higher-education and research policy, the production of S\&T indicators, especially concerning research funding and expenditure, and the introduction of new communication technologies in higher education. $\mathrm{He}$ is co-ordinator of the indicators activities in the PRIME network of excellence and chair of the PRIME indicators conference series.

Michael Dinges is a researcher and project manager at Joanneum Research. Institute of Technology and Regional Policy in Vienna, where he is in charge of the thematic field 'Evaluations'. He graduated from the University of Vienna with a degree in economics and social sciences. His main areas of expertise are: evaluation methods; technology and innovation policy; S\&T indicators; and transition economics.

large parts of public budgets for science and for implementing science policy. However, a council needs also to have some collaboration with scientists to fulfil its mission of implementing government policies and priorities. Since scientists do not always readily accept government policies, a council will have to balance the interests of government on the one hand, and those of scientists and their institutions on the other, being more or less responsive to both parts.

From this double-sided relationship of the councils emerges our first question; are councils mainly responsive to government or scientists? In its essence, this question concerns the driving forces of science (science policy or scientists), but we will here be narrower in focus and concentrate on how responsive research councils are to science policy. Responsiveness is dependent on several factors, among them the councils' autonomy (dependent on the national traditions of governance), the mission or profile of a council and how science policy is coordinated horizontally internally in the council and between councils. Applying a set of variables to analyse responsiveness, we assume that the eventual evidence for a council being highly responsive to policy initiatives actually indicates that policymakers have some steering capacities towards science.

Secondly, we are interested in assessing national variations by investigating the question whether research councils have developed along national trajectories or whether there are homogeneous developments across the compared countries. Homogenous developments will indicate some general trends in science policy, while disparate developments indicate that science policy is mainly a national enterprise.

\section{Theoretical approaches}

To be able to study the development of research councils and their roles, we need a flexible approach accounting for the complex relationships between a council and its surroundings. Research councils might maintain several roles, depending on the parts of the research system they address and the purpose of the actions they initiate.

Towards the scientific community, a council's main role will normally be as a funding agency for research projects, but it might also serve as a developer of research policy through choice of instruments, priority areas and its selection mechanisms. Towards policy-makers, it will act as an agency implementing policies, but might also have its own agenda of increasing public budgets for research or the implementation of specific strategies and schemes for targeted fields of research, the construction of research facilities, and so on. Thus most councils maintain more roles than as an agent for the government, and consequently a council's actions will be dependent on its relationships with more than one part and on its ability to fulfil more than one type of task.

\section{Principal-agent approach}

Various aspects of science policy and the relationships between institutions of science have often been analysed over the last ten years by use of principalagent theories (Guston, 1996; van der Meulen, 1998; Braun, 2003; Braun and Guston, 2003; Caswill, 2003; van der Meulen, 2003; Gulbrandsen, 2005). Principal-agent theory normally assumes an asymmetrical relationship between principal and agent; the principal is hiring the agent to contribute to the achievement of the principal's goals (Petersen, 1993). This approach can be applied to science policy and the relationships between institutions in the scientific system at several levels and in a hierarchy of relationships (Guston, 1996) but, in our context, we use the model for explaining the relationships between government and council on the one hand, and council and the institutions of science on the other.

Several analyses have used principal-agent theory for analysing research councils' double relationship towards government and scientists (for instance, Caswill, 2003; van der Meulen, 2003; Gulbrandsen, 2005). These approaches analyse research councils as agents for government in the government's efforts to realise science policy goals. The relationship is asymmetrical, since government is contracting the council and the council is dependent on government allocating the necessary resources and legal authority empowering the council to perform the actions deemed necessary to fulfil its part of the contract. 
The relationship is, however, not completely asymmetrical, since government cannot terminate the contract without inflicting large costs and considerable political debate, because normally there is no more than one council for each scientific domain in a country, often less. The asymmetry in the relationship will also be modified by the relationship between the council and the scientific community, a relationship consisting of several elements. First, a council needs to evoke the necessary interest in scientists to apply for the support schemes it provides (Arnold, 2004). This is usually no problem as scientists will be eager to apply for funding. Still the research council will have to rely heavily on contact with scientists to be sure their programmes and instruments are in accordance with actual and potential developments of science.

Secondly, a council will normally engage scientists on boards and committees at various levels deciding the use and design of instruments, on selection committees, and on the council board. Third, councils often recruit senior officials and leaders from scientific positions. In total, this makes strong connections and dependencies between the council and the scientific community. In addition, councils often take the role as advocates for the interests of science, by promoting arguments for increased science budgets, the need for new efforts in certain scientific fields or for infrastructures.

The relationship can also be completely reversed, as government will be dependent on scientists to develop its science policy (Braun, 2003), and a council can even have this role as part of its mandate (Skoie, 2000). In some cases, a council can thus identify more closely with the interests of the scientists than those of the government, and can act as a mediator of scientists' views or initiate processes of policy developments by itself.

In line with these examples and arguments, as well as other analysis (van der Meulen and Rip, 1998; Caswill, 2003), we will argue that research councils have to be responsive to both government and scientists to be able to fulfil their mission. They can therefore be expected to develop their organisation, strategies and actions with the aim of satisfying policy-makers, scientists or both, depending on the

\section{Research councils can be expected to develop their organisation, strategies and actions with the aim of satisfying policy-makers, scientists or both, depending on the strengths and weaknesses of the combined relationships}

strengths and weaknesses of the combined relationships with both of them.

The actual position between government and science in most cases will be somewhere in between and be susceptible to change according to variations in government policies, composition and policies of the board, legal status, authority delegated, and so on. In this way, the council will be intermediating between the interests of policy-makers and the scientific community (Braun and Benninghoff, 2003; van der Meulen, 2003).

\section{Research councils as responsive institutions}

Research councils should also be treated as organisations with system characteristics influencing their responses. A much used distinction of organisations is between rational, natural and open systems (Scott, 1992; Thompson and McHugh, 1995). Councils will probably display elements of them all, but we find the definition of the open system to fit research councils best. An open system is embedded and dependent on its relationships with its surroundings, has undefined boundaries and frequent interaction with other organisations. Internally, open systems can be more loosely coupled, and the various parts and departments can be pursuing their own strategies independent of the overall strategy of the organisation. Loose coupling might lead to tensions internal to the council, between council and government or between council and scientists; there is also the possibility that the council maintains mixed relationships or responses at the same time (van der Meulen, 2003).

An analysis of the Norwegian Research Council in the mid 1990s found, for example, strong tensions between the administration and the board (Statskonsult, 1994), while there have also been conflicts regarding the priorities between basic and mission-oriented research (Skoie, 2000). Tensions between council and Government are seen in the case of Austria, where ministries found alternative agencies to fund research instead of trying to change the mission of the existing ones (Arnold, 2004), and in the case of Norway, where the councils' role as policy advisors has been unclear (Arnold et al, 2001).

Another study shows various relationships in a council according to operative roles of council departments; for example, the scientific staff who manage peer-review processes and monitor scientific progress can have a stronger affinity with the interests of the scientists than the administrative staff who will orient themselves towards expectations from the government (Caswill, 2003). We should also be aware that councils sometimes might act as natural systems - organisations in which the participants share the common interest of surviving as a system - in times of organisational restructuring, of which there are examples in the countries examined. In such situations, those identifying with the organisation are expected to contribute to its defence. 
As open systems, the responses of councils will to a varying degree be dependent upon others. Among theories on institutional responses, the resource dependency approach put emphasis on the dependencies of an organisation and how it adapts to them (Scott, 1992), and the possibilities of meeting incompatible requirements from various external actors and the choice of various strategies to adapt to these requirements (Oliver, 1991).

A research council is normally very dependent on government for its resources, and this will most likely make the council responsive to the requirements and policies of those providing the resources as dependency will increase with the amount of resources coming from the outside. If there is more than one provider of resources, we should expect greater freedom in the choice of responses, as the council might be able to seek out alternative sources of funding and to juggle between various expectations and requirements.

The strategic contingency approach, on the other hand, stresses the freedom of an agency to determine its own actions against the limitations of internal and external structures (Scott, 1992). An organisation will always have several choices open for action, and the decision as to which action to take will depend on a variable set of interests, goals and powers opting for a "functional fit" between external requirements and the internal organisational structures they require (Thompson and McHugh. 1995). For a research council, this approach implies that there might be several options for response, and that responses will be dependent on from whom, and with what force, the external pressures come, and how the internal organisation is prepared and co-ordinated to meet the pressures.

\section{Types of council and ways of delegation}

The relationship between council and government can be understood as maintained through an explicit or implicit 'contract', regulating the tasks and mandate of the council, that is, its mission. Following Braun (1998), funding agencies can in general be divided into three categories according to their role in the realisation of science policy. Science-based agencies serve all disciplines, respond to problems raised by disciplinary communities and tend to propose disciplinary solutions, that is, they tend to choose disciplinary-oriented instruments for their funding.

Strategic agencies serve the solution of particular problem areas (for instance, health, environment, public services), respond to problems raised by disciplinary communities, the scientific community outside academic institutions and external actors. Strategic agencies seek disciplinary and inter-disciplinary solutions to the problems posed. According to Braun, this is the largest group of intermediaries.

Political agencies respond to problems raised by external actors, and tend to utilise multi-disciplinary schemes. These categories can be considered ideal types, where the tasks and missions of the council change as policies and practices develop over time, and councils might change their roles and their position in the typology according to the development of policies.

Braun also points to variations in use of instruments to help solve scientific problems by the various types of agencies (Braun, 1998). A science-based agency tends to select discipline-oriented solutions and a political agency is oriented towards the solution of broader problems and tends to select multidisciplinary solutions. Thus, the way a council tries to accomplish its mission is a matter of the way it chooses to delegate the solving of scientific problems to scientists.

Following Braun (2003) ${ }^{1}$ once more, we can typify how the forms of delegation have developed over time. From 'blind delegation' being the typical form from the early days of science up to the 1960s, delegation developed through a transition period when curbed public spending resulted in 'incentive' and 'steady state' modes by the end of the 1970s, before the more formal 'contract' mode and the 'network' mode emerged during the 1990s. The modes of delegation are reflected in the choice of selection mechanisms and instruments used by councils, and we can assume that use of instruments will be dependent on the type of council and type of delegation.

\section{Analytical model and methodology}

Following from the theoretical discussion, a council's relationships with its surroundings are seldom characterised by a distinct or unambiguous relationship to a principal. Its responses to science policy will thus not depend solely on the relationship with the government, but also partly on the relationships between council and scientists, and partly on the internal organisation of the council, its dependencies and abilities to exert strategic actions. These elements are difficult to analyse, as they are constituted by a complex mix of history, legitimacy, use and balance of power, institutional perceptions, and so on. Our approach is to simplify these relationships into a model that, as far as possible, can be operationalised and compared across councils and countries, as well as taking into account the availability of relevant data (formalised in Figure 1).

We first assume that transferring funds to councils is the main way government has of implementing research policies, or, to use the principal-agent categories, to exert its role as principal towards the council. Since councils are dependent on government funding to be able to fulfil their mission and the expectations of scientists, according to the resource-dependency approach, these transfers create a dependency towards government, which entails loyalty and responsiveness towards government policy 


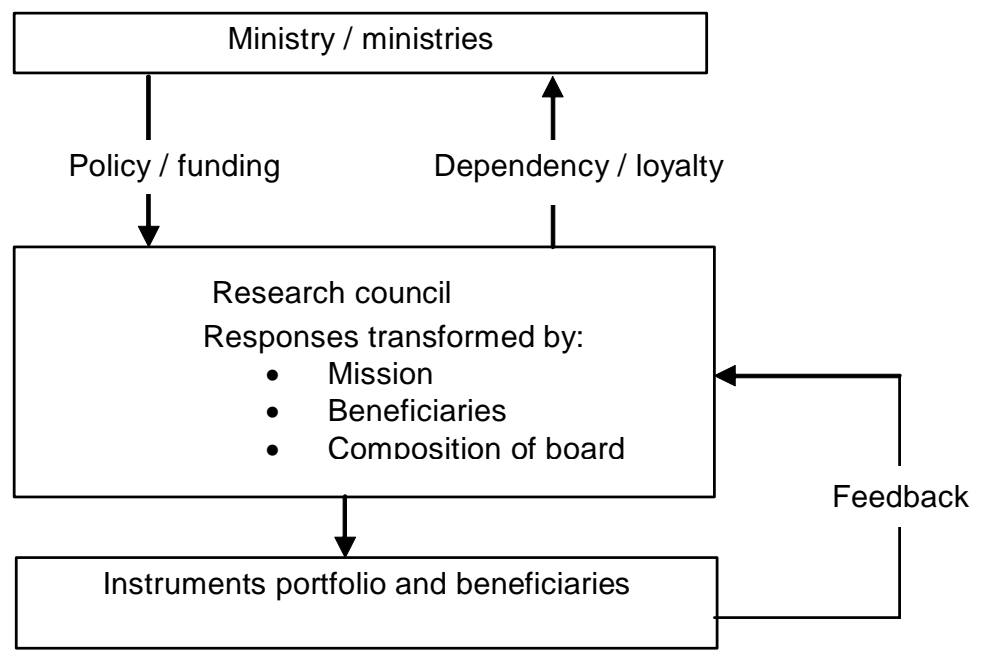

Figure 1. Analytical model

as well. More specifically, we assume a council that is dependent on one main source of funding (for instance, a ministry) will tend to be responsive to the wishes of this actor, while a council having several large sources of funding can introduce more freely its own strategies or make compromises among the priorities of the different partners.

The number of funding sources and their relative strength in terms of funds transferred is thus the first proxy we introduce for our analysis, being aware that transfer of funds is not the only way of exerting research policy through councils. Direct instructions, legislation and statutes regulate the institutional freedom, and the national traditions of political culture, style of government, distribution of power and so on will be of influence. We thus have to be aware of the general political context in which the transfers take place.

The responsiveness created through the combined dependency/loyalty towards a council's sources of funding will be transformed by several factors internally in the council. First, it will be affected by the type of council and its mission. A council is likely to 'translate' government policy into operative programmes that, from the council's point of view, contribute best to the fulfilment of its mission. We thus use the council's mission statements as a broad indication for the expected direction of a council response.

We are aware that such statements can be formulated in a rhetoric or ideal language and should be treated carefully but, on the other hand, we are also aware that such statements often are regarded as so important that considerable debate is evoked when they are altered. In addition, we can make a more robust account of whom the council actually serves by examining the real allocation of funds. We assume that a council having only one type of beneficiary institution (for instance, universities) or only one sector of society (for instance, agriculture research) will be dependent on being recognised by these, and thus will be more inclined to transform policies towards their needs. The mix of beneficiaries can thus influence a council's responses.
Secondly, responses to government policy will be transformed by the council board, as it will be the decisional body for how to implement policies into practice. We find it likely that a council board with a majority of scientists will be more responsive to the needs of science, and thus tend to transform policies into actions deemed favourable from the scientists' point of view. On the other hand, a council board with a majority from political circles or industry, will probably be more directly responsive to policymakers, industrial or societal needs.

We use the composition of the board as another proxy for how a council is likely to respond to policies, being aware that the composition depends on who has the right to nominate the members, which again is part of the historical tradition and embeddedness of the council in national policy. We should also be aware that responses might be affected by the size and internal organisation of the council into divisions, and so on, but an analysis of institutional 'looseness' is beyond the possibilities of what we can do in this context.

For assessing the councils' responses to policy changes, we use the categories of funding instruments as a proxy, implying new instruments used or changes in relative size of budgets might indicate responses to external influences. In general, this implies that a council responsive to government will respond to changes in policy by changing its own portfolio, that is, bringing in new instruments to promote goals set by policy-makers or change the actual distribution of resources between the existing instruments.

On the other hand, we can assume that a nonresponsive council will keep to instruments well known and acclaimed by the beneficiaries. We are aware that this is a simplification, as science policy does not (always) work in this one-dimensional way, and there will be feedback on the actions of a council. The council's response to policy can thus be welcomed by all parties and does not necessarily imply compliancy towards government.

By observations of these proxies, we cannot in any exact way establish criteria to assess how responsive 


\section{Austria, Norway and Switzerland were chosen because they resemble each other in research organisation and characteristics of the research funding system, and they have research councils operating competitive-based funding instruments at arm's length from research performers}

a council is to policies, and observations should be evaluated on the background of the specific national context. Our data on mission statements, composition of boards and councils and sources of funding has been collected from annual reports, government documents and prior evaluations and analysis. For contextual analysis, we rely on existing material, as well as our knowledge of the national science systems. Data on beneficiaries and instruments was made available through a study of project funding for the period 1970-2005 in several countries. ${ }^{2}$

The choice of comparing Austria, Norway and Switzerland, is partly because these countries resemble each other in research organisation and characteristics of the research funding system, and partly because they have one or more research councils operating competitive-based funding instruments at arm's length from the research performers. This in contrast to France, for example, where Centre National de la Recherche Scientifique (CNRS) is a combined funding and research operating agency, or Italy, where the former research council CNR was fundamentally changed (Potì and Reale, 2005). The general methodology applied for funding data and comparisons is discussed extensively in other papers (Lepori, 2006b; Lepori et al, 2006a; 2006b; 2007a; 2007b). ${ }^{3}$

When analysing the institutional level as opposed to the national level, we encounter more often breaks in time series and ways of classifying. We are also aware that, even if concepts and terminology might seem homogenous, the underlying understanding of what it means might vary over time, between institutions and countries. When we present developments in research policy and organisation at macro level, at research councils' level, as well as developments of research funding, the reader should be aware that this could not be done at a very detailed level, and that some elements or developments have had to be omitted for the sake of simplicity.

\section{Research councils in the three countries}

This section briefly introduces the research councils in the three countries (Table 1) and their historical developments in terms of years of establishment, reorganisations and mergers, with some references to the debates leading up to reorganisations.

\section{Austria}

The Austrian Science Fund (FWF) and the Austrian Industrial Research Promotion Fund (FFF) were both created in 1967. Combined they have held the largest share of project funding in Austrian research, accounting for more than $54 \%$ of total project funding volume in 2002 (Dinges, 2006). By the reform act in 2004, the governance structure of FWF was somewhat changed, but its overall structure was not altered. From 1967 until 2004, FFF was the main funding agency for industrial research in all branches, but a noteworthy feature of the Austrian research funding system was the establishment of technology-oriented support measures outside FFF from the end of 1970s.

In 1987, the virtual Innovation and Technology Fund (ITF) was established, largely steered by a board dominated by ministries, whereas its funding was administered jointly by FFF and the ERP. ${ }^{4}$ The Technologie Impulse Gesellschaft (TIG) was created in 1998 and the Austrian Space Agency (ASA), established 1972, got involved in research and technology programme management, as it operated the European Space Agency in Austria and started to prepare the nanotechnology programme on behalf of

Table 1. Research councils included in the analysis

\begin{tabular}{|c|c|c|c|c|}
\hline Country & Code & Full name & Established & Dissolved \\
\hline Austria & $\begin{array}{l}\text { FFF } \\
\text { FWF } \\
\text { FFG }\end{array}$ & $\begin{array}{l}\text { Austrian Industrial Research Promotion Fund } \\
\text { Austrian Science Fund } \\
\text { The Austrian Research Promotion Agency }\end{array}$ & $\begin{array}{l}1967 \\
1967 \\
2004\end{array}$ & 2004 \\
\hline Norway & $\begin{array}{l}\text { NTNF } \\
\text { NLVF } \\
\text { NAVF } \\
\text { NFFR } \\
\text { NORAS } \\
\text { NFR }\end{array}$ & $\begin{array}{l}\text { Royal Norwegian Council for Scientific and Industrial Research } \\
\text { The Agricultural Research Council of Norway } \\
\text { The Norwegian Research Council for Science and the Humanities } \\
\text { The Norwegian Council for Fishery Research } \\
\text { The Norwegian Research Council for Applied Social Science } \\
\text { The Research Council of Norway }\end{array}$ & $\begin{array}{l}1946 \\
1946 \\
1949 \\
1972 \\
1987 \\
1993\end{array}$ & $\begin{array}{l}1993 \\
1993 \\
1993 \\
1993 \\
1993\end{array}$ \\
\hline Switzerland & SNF & The Swiss National Science Foundation & 1952 & \\
\hline
\end{tabular}


the Ministry of Transport, Innovation and Technology (BMVIT) in 2000.

There was thus some fragmentation in the organisational structure, which was ended when the Austrian Research Promotion Agency (FFG) was established in 2004 through a merger of FFF, TIG, ASA, and the Bureau for International Technology Co-operations (BIT). Upon the merger, FFF was dissolved and FFG was set up as a limited corporation on behalf of the Ministry of Transport, Innovation and Technology (BMVIT) and the Ministry of Economy and Labour (BMWA).

\section{Norway}

Norway established three research councils during the late 1940s: one was devoted to industrial needs and technological development (NTNF); one to the needs of agriculture (NLVF); and one was academic (NAVF). Following a discussion in the 1960s of the needs in the fisheries, a council devoted to this industry was established in 1972 (NFFR), while a fifth devoted to applied social sciences was established in 1987 (NORAS). ${ }^{5}$ By the early 1990s, Norway thus had five councils with a mixed portfolio of academic, technological development and innovation goals.

After a discussion focusing on lack of coordination, excess resources used for administration, lack of integration between basic and applied research, problems of handling relationships with external partners, and so on, the five councils were merged into NFR in 1993 (Skoie, 2000; 2005). The new council was divided into six non-disciplinary operational divisions, all integrating both basic research and innovation. After an evaluation of the council in 2001 (Arnold et al, 2001), it was reorganised into three divisions. By 2002, the council allocated $43 \%$ of the total project funding volume in Norway.

\section{Switzerland}

The Swiss National Science Foundation (SNF) was established in 1952, and is the single most important organisation for project funding at the national level, accounting in 2002 for slightly less than $50 \%$ of the total funding volume and for more than $60 \%$ when excluding international agencies (Lepori, 2006a). The organisation of the SNF has been stable throughout its 50 years of existence. Most changes have been pushed by quantitative expansion, leading to growth in the number of members of the National Research Council (NRC, the main body of the council) and of the secretariat, and to its organisation in divisions. Political intervention in the SNF internal organisation and functioning has been practically absent, and Switzerland has thus had only one research council.

\section{Empirical evidence}

This section presents the empirical evidence along the proxies outlined previously. The findings will be discussed in the next section.

\section{Sources of funding}

The Austrian councils, FFF and FWF, were largely dependent on the annual federal budget (Table 2). In the case of FFF, the annual federal budget was the

Table 2. Main sources of funding for research councils (\% of total annual budget)

\begin{tabular}{|c|c|c|c|c|c|c|}
\hline Council & Sources of funding & 1970 & 1980 & 1990 & 2000 & 2005 \\
\hline$F F F(A U)$ & $\begin{array}{l}\text { Federal Government } \\
\text { Austrian National Bank } \\
\text { Loans, returns, etc } \\
\text { Anticipation Budget } 2001\end{array}$ & 100 & 100 & $\begin{array}{l}82 \\
18\end{array}$ & $\begin{array}{l}20 \\
14 \\
14 \\
46\end{array}$ & \\
\hline FWF (AU) & $\begin{array}{l}\text { Federal Government } \\
\text { Austrian National Bank/National Fund } \\
\text { Commissioned Federal programmes }\end{array}$ & 100 & 100 & $\begin{array}{l}87 \\
13\end{array}$ & $\begin{array}{r}58 \\
34 \\
8\end{array}$ & $\begin{array}{l}57 \\
32 \\
11\end{array}$ \\
\hline FFG (AU) & & & & & & NA \\
\hline \multirow[t]{3}{*}{ NTNF (NO) } & Ministry of Industry & 76 & 43 & 71 & & \\
\hline & Ministry of Petroleum and Energy & 7 & 21 & 12 & & \\
\hline & $\begin{array}{l}\text { Other ministries/public } \\
\text { Football pool funds }\end{array}$ & 15 & $\begin{array}{l}20 \\
12\end{array}$ & $\begin{array}{l}4 \\
9\end{array}$ & & \\
\hline \multirow[t]{3}{*}{ NLVF (NO) } & Ministry of Agriculture & & $\begin{array}{r}12 \\
5\end{array}$ & 54 & & \\
\hline & Football pool funds & 80 & 66 & 29 & & \\
\hline & Industry & 9 & 16 & 10 & & \\
\hline \multirow[t]{2}{*}{ NFFR (NO) } & Ministry of Fisheries & 100 & 73 & 82 & & \\
\hline & Other ministries & & 2 & 12 & & \\
\hline \multirow[t]{2}{*}{ NAVF (NO) } & Ministry of Education and Research & & 80 & 54 & & \\
\hline & $\begin{array}{l}\text { Other ministries/public } \\
\text { Football pool funds }\end{array}$ & 82 & NA & 26 & & \\
\hline \multirow{3}{*}{ NFR (NO) } & Ministry of Industry & & & & 28 & 19 \\
\hline & Ministry of Education and Research & & & & 31 & 40 \\
\hline & Other ministries/public & & & & 39 & 37 \\
\hline $\mathrm{SNF}(\mathrm{CH})$ & Ministry of Home Affairs & 100 & 100 & 100 & 100 & 100 \\
\hline
\end{tabular}


sole funding source until 1981, while, from then on, the Austrian National Bank (OeNB) started to contribute (22\% of the total by 2000$)$. From around 1990, FFF started to administer funds from the virtual Innovation and Technology Fund (ITF) as well as European Union regional funds. Since 1997, special funds from the federal budget have been added, but at the cost of the regular budget. To provide maximum stability in its funding, FFF took money from the following year's budget, and utilised financial returns from loans and guarantees.

In 1995 and 1999, the annual federal budget devoted to FFF was cut by more than $30 \%$, leading to a severe financial crisis. Also for FWF, the National Bank provided some funding from 1982 onwards and state support was reduced during the mid-1990s. From 2004 onwards, National Bank funding for both councils were allocated by the newly founded National Foundation. Also for FFG, funding largely stems from the federal budget. ${ }^{6}$

In Norway, the mission-oriented councils NTNF (technology), NLVF (agriculture) and NFFR (fisheries) were mainly funded by the ministries responsible for the equivalent sectors of society according to the "sector principle" of governance (Skoie, 2000). Typically, the NTNF got more than 70\% of its funding from the Ministry of Industry. The academically oriented council NAVF had, on the other hand, a more diversified income, especially from the 1980s on. Except for the fisheries council in its early years, no council has been dependent on one single source of funding, since for all councils there were other public sources or industry contributing.

A system that reserved parts of the income from the nationalised system of football betting for research purposes was established shortly after World War II; for this, Government had no voice in the distribution, increasing councils independence from Government (Skoie, 2005). This mechanism contributed as much as $80 \%$ of the funding of the NLVF and NTNF in 1970, while it later saw reductions and was abandoned altogether in 2002. Since the establishment of NFR in 1993, no ministry contributes as much as half of its funding. The Ministry of Education and Research is the largest source, but 15 other ministries allocated funding to the council in 2005, of which six contributed more than $5 \%$ of the total.

In the Swiss case, the SNF, over the years, has received virtually all its funding from central Government through the Ministry of Internal Affairs. The framework decisions on financial allocations to SNF have been the most important possibility of influencing SNF and of setting specific objectives by the state, and all discussion concerning the SNF policy and role have taken place in this context.

\section{Mission and beneficiaries}

The Austrian council FFF was set up as a responsive mode agency for industrial R\&D projects. According to the 2004 evaluation of the council, FFF has remained "remarkably true" to this mission (Arnold et al, 2004). Even so, the council has deviated somewhat from this mission in the last ten years of its existence as, in co-operation with ministries and other actors, it also managed programmes of a topdown character (for instance, ITF programmes) and those designed and steered by ministries, and defined specific programme-like schemes for the responsive mode calls.

FFF beneficiaries were mostly the business sector. In 2002, about $26 \%$ of FFF projects included science-industry collaborations and, at maximum, an estimated $31 \%$ of FFF funds were for academia (Arnold, 2004). Since the reorganisation into FFG in 2004, the mission has still been predominantly towards supporting strategic research for the benefit of the economy and business, but science-industry linkages are supposed to be higher than was the case of FFF. Ministries can assign programme management to promote technology development to FFG.

The FWF had a mission towards basic and academic research, and with the same responsive mode principle of operation as FFF. It is noteworthy that the mission states FWF has an equal commitment to all fields of science, which has consequences for virtually all programmes in the way that all measures are generic in terms of scientific disciplines and no $a$ priori distribution of the funds over different disciplines exists (see van der Meulen, 2004). The mission has been realised by FWF funding mainly basic research almost exclusively in the higher education sector.

During the 1970s, the Norwegian councils' close links to the ministries affected their mission, which, however, had some noticeable variations (Skoie, 2005). The technological-oriented NTNF had a mission towards applied sciences and industrial relevance, and should promote technological and natural science and the use of scientific results for the benefit of industry. Responding to stagnating industrial developments and criticism of the abilities of the research system to contribute to the needs of industry, references to economic competitiveness and growth became more direct (Skoie, 2005).

For the beneficiaries, until the mid-1980s, NTNF had its own research institutes, to which a large part of its funding was allocated (Figure 2). After criticism of this arrangement in 1981, the institutes became independent units and a large part of the portfolio was allocated to private and industrial research, and a small part to universities (Arnold, 2001). For the two specialised councils, NLVF and NFFR, the mission statements had a commitment to the agricultural and fisheries sectors and the needs of industry. NFFR allocated considerable funding to higher-education institutions, with an increase to research institutes and a decrease to industry over the years.

The 1970 mission statement of the academicoriented NAVF was to promote scientific research in all scientific fields. A debate during the 1970s 


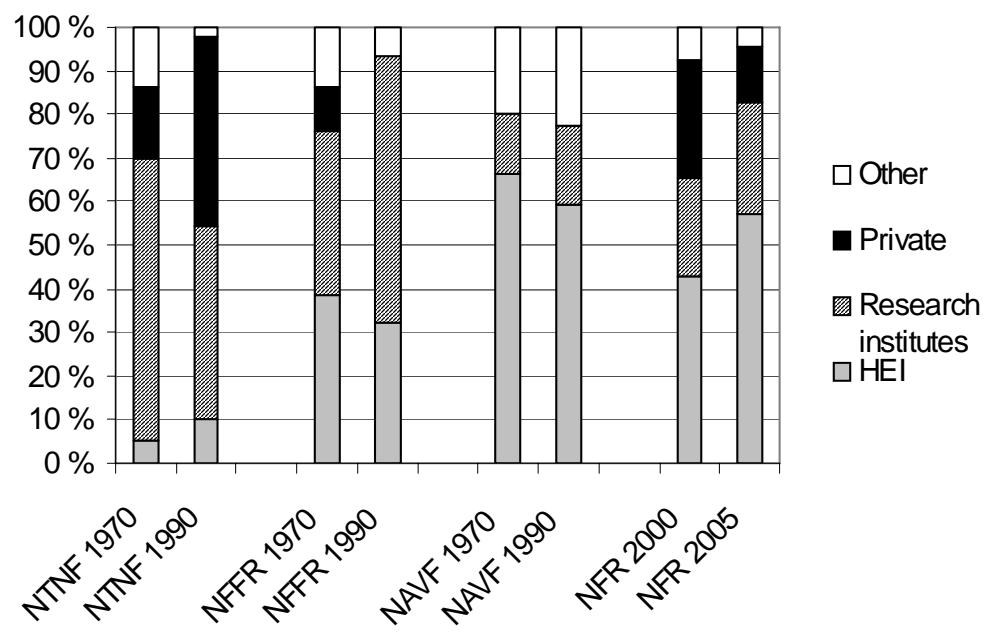

Figure 2. Funding from Norwegian research councils by beneficiary Note: $\quad$ Breakdown by beneficiaries not available for NLVF

concerning a Government proposal to establish a new research council for funding research for societal planning resulted in the establishment of a new division within the NAVF, and the mission statement came to include “... research for society's planning needs” (Skoie, 2005). After a separate council for applied social science was established in 1987, the mission statement again refers only to the promotion of the scientific disciplines. Around $60 \%$ of the NAVF funding in 1990 went to academic institutions, $18 \%$ to research institutes, and $22 \%$ to individuals and national priority programmes outside the regular institutional structure.

After the former councils were merged into NFR 1993, the mission statement gives this council much wider responsibility: it should increase the knowledge base and meet society's demand for basic and applied knowledge, and for innovation. The amalgamation into one council with broader objectives and services seems to have caused a vague and general mission statement without favouring any sector, type of research or discipline. The broad mission is reflected in the composition of beneficiaries (Figure 2), but a slight turn towards the benefit of highereducation institutions is observable in the 2000-2005 period, while private beneficiaries have had a reduction from $27 \%$ to $13 \%$ of the total.

The mission of the Swiss SNF is described in its statutes and in the research act of 1983. The main aims are to support independent (investigatordriven) research in universities and research institutes, while interdisciplinary and problem-oriented programme research comes second and training of young researchers also plays a part. SNF can also be charged with executing national research programmes on subjects decided by the Swiss Government and to fund national competence networks in research.

The option of funding laboratories directly was discarded at the creation of the SNF, which deals directly with the principal investigators with very little involvement of their university. Higher-education institutions receive about $90 \%$ of the total funds: this share has not changed significantly in recent years. The rest is divided among some public-research institutes, individuals and some consultancy companies. Direct funding to private companies is almost non-existent and SNF cannot by statute fund research of direct commercial interest.

\section{Composition of board and its nomination}

From their establishment, FWF and FFF were given a strongly autonomous status since governance structures were dominated by beneficiaries rather than by ministries (see Arnold, 2004) and, until 2004, their governance structures remained unchanged (Table 3). FFF was governed by a presidium that consisted of 18 members, where the 11 voting members were a subset of the Board, which in turn consisted of 31 members appointed entirely by the Social Partners ${ }^{7}$ except for three non-voting members appointed by ministries.

The governance structure of FFG is entirely different, since it is a limited corporation on behalf of BMVIT and BMWA, which appoint the two managing directors via a tendering procedure approved by the supervisory board dominated by ministries. FWF, on the other hand, was largely governed by

The main aims of the Swiss SNF are to
support independent research in
universities and research institutes,
while interdisciplinary and problem-
oriented programme research comes
second and training of young
researchers also plays a part

The main aims of the Swiss SNF are to support independent research in universities and research institutes, while interdisciplinary and problemoriented programme research comes second and training of young 


\begin{tabular}{|c|c|c|c|c|c|c|c|c|}
\hline & \multicolumn{2}{|c|}{$\begin{array}{c}\text { Austria } \\
\text { prior to } 2004\end{array}$} & \multicolumn{2}{|c|}{$\begin{array}{c}\text { Austria } \\
\text { after } 2004\end{array}$} & \multicolumn{2}{|c|}{$\begin{array}{c}\text { Norway } \\
1980\end{array}$} & \multirow{2}{*}{$\begin{array}{c}\text { Norway } \\
2004 \\
\text { NFR } \\
\text { Board }\end{array}$} & \multirow{2}{*}{$\begin{array}{c}\text { Switzerland } \\
\text { SNF } \\
\text { Council }\end{array}$} \\
\hline & $\begin{array}{c}\text { FWF } \\
\text { Assembly }\end{array}$ & $\begin{array}{l}\text { FFF } \\
\text { Board }\end{array}$ & $\begin{array}{c}\text { FWF } \\
\text { Supervisory } \\
\text { Board }\end{array}$ & $\begin{array}{c}\text { FFG } \\
\text { Supervisory } \\
\text { Board }\end{array}$ & $\begin{array}{l}\text { NTNF } \\
\text { Board }\end{array}$ & $\begin{array}{l}\text { NAVF } \\
\text { Board }\end{array}$ & & \\
\hline Policy & 5 (nv) & 4 (nv) & 3 & 7 & 1 & 4 & & \\
\hline Higher education & 52 & $3(n v)$ & $3^{a}$ & & 1 & 4 & 3 & 100 \\
\hline Non-university Sector & 4 & & & & 1 & 1 & 2 & \\
\hline $\begin{array}{l}\text { Trade/labour/ind-ustry } \\
\text { associations }\end{array}$ & 6 & 24 & & 3 & 5 & 1 & 2 & \\
\hline Others & $5(n v)^{c}$ & & $1^{\mathrm{b}}$ & & & 2 & 1 & \\
\hline Total voting members & 62 & 24 & 7 & 10 & 8 & 12 & 8 & 100 \\
\hline
\end{tabular}

the scientific community. The Assembly of Delegates, the Executive Board and the Kuratorium, which takes the research funding decisions, all had a majority from higher education.

Whereas internal regulations were optimised and not altered dramatically by the 2004 reform, a supervisory board was also introduced for FWF (FTFG, 2006: §5.a), deciding FWF long-term work plans and appointing and recalling the management. Hence, the strategic competencies of the supervisory board are extensive and policy-makers now actively participate in the decision-making process as three out of seven supervisory board members are appointed by ministries. Of the rest, three are appointed by the Assembly of Delegates (dominated by universities).

The three strategic Norwegian councils had a considerable representation from industry, as many as two thirds of the NTNF members coming from industry in 1990. The nomination and appointment of the board were, in the early period, the responsibility of the council assembly, while, in 1990, the appointment was transferred to the Ministry of Industry. Also in the agricultural council (NLVF) the board until the 1980s was appointed by the council, while this right later was transferred to the Government, although the institutions represented had kept their right to nominate the members.

For the fisheries council (NFFR), members of the board were nominated by the Ministry of Fisheries and appointed by the Government. The board of the NAVF was dominated by scientists and had no industrial representation. In the early period, the Ministry of Education and Research nominated four of the board members and four others were nominated by the assembly, while later the Government appointed the majority of the representatives. Since the establishment of NFR, the Government has kept more at arm's length, as it has not appointed any Government official except in cases where they have come from Government research institutions at a relative long distance from central Government.

The internal organisation of SNF is based on a national research council (NRC) composed of 100 researchers (mostly university professors) spread over scientific disciplines. NRC is more a collection of representatives of the scientific disciplines than a corporate body. In the past, three-quarters of the members have been chosen by the SNF itself, while the rest has been nominated by the Government (in practice they have been co-opted by the NRC). Since 2000, all members have been elected by the committee of the SNF foundation council through an opencall procedure.

The whole organisation of the SNF emphasises the role of the individual members of the NRC, who are responsible for the choice of the reviewers of project proposals, and for submitting the propositions of decisions to the NRC. In addition, there is a foundation council linking SNF and the stakeholders composed of representatives of the universities, the central state and the cantons, scientific societies and the world of culture. Most of the strategic documents and decisions are taken by NRC together with the secretariat.

\section{Instruments and funding allocation}

For a long time, the Austrian FFF operated bottomup R\&D project funding for all branches as its sole funding instrument. Except for some technologyspecific initiatives, FFF virtually did not extend its instrument portfolio, and programmes geared towards science-industry collaborations, networks and thematic-oriented programmes largely passed FFF by (Arnold, 2004). Only in the beginning of the 1990s, FFF became partially involved in thematicoriented, top-down programme implementation through the programme management of a series of technology programmes designed and launched by BMVIT (Figure 3). ${ }^{8}$ 


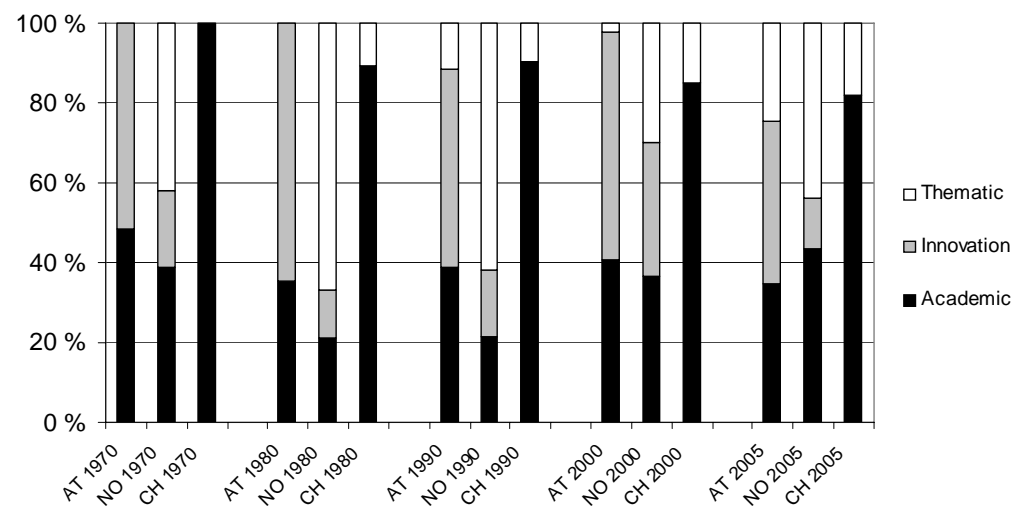

Figure 3. Instruments by main categories

The tradition of bottom-up research funding did not vanish with the creation of FFG, since the funding scheme was converted into FFG General Programmes, still by far the largest direct research funding instrument for industry. Funding of individual research projects has also been the single most important instrument of FWF. Until 1990, the portfolio of instruments consisted mainly of individual research projects and thematic priority programmes; since then, the programme portfolio has increased dramatically. Today it consists of about 15 programmes, some of which are mandated by BMBWK and BMVIT. In 2005, mandated programmes accounted for $12 \%$ and individual research projects for $50 \%$ of total funding.

Until the mid-1980s, the Norwegian NTNF largely used instruments dedicated to its own research institutes; these were mostly thematic instruments. When most institutes became independent units, a large part of the portfolio was allocated to private and industrial research (Arnold et al, 2001). Even if NTNF allocated some resources to universities as $\mathrm{PhD}$ and travel grants, its instruments were almost solely designed to promote innovation or thematic programmes. The fisheries council (NFFR) utilised almost exclusively thematic instruments operated in response mode in the earlier period and as larger programmes in the later years $(94 \%$ of the total in 1990).

In the 1970s, NAVF used academic instruments allocated as individual grants and free projects in responsive mode. These developed partly into programmes during the 1980s. In the late 1980s, national priority areas were introduced and defined by Government, and administered by the council. By 1992, more than $60 \%$ of the council's funding was organised through programmes and national priorities.

For the amalgamated council, NFR, about $40 \%$ of the funding has been allocated through academic instruments, while instruments for innovation have decreased and thematic instruments increased. The number of instruments has proliferated, especially those with a thematic content, such as targeted programmes, centres of excellence and programmes for basic research. By 2005, less than $20 \%$ of the total was allocated to the 'classical' academic instruments of grants and free projects and, by 2006, the council stopped giving individual grants. More than $80 \%$ of funding for centres of excellence and basic research programmes was allocated to higher-education institutions.

The Swiss SNF has dominantly allocated funding by responsive-mode instruments. In 2005, about $80 \%$ of the budget was attributed this way, either as research projects $(60 \%)$ or as individual grants (20\%). Thematic programmes to answer to urgent social and political needs were introduced in the 1970s (national research programmes), while SNF also managed a set of technological programmes in the 1990s (priority programmes). These have been replaced since 2000 by an instrument to finance national competence networks in research (NCCR), with a stronger orientation towards basic research. Overall, thematic instruments appeared in the mid1970s and reached about a quarter of the total SNF budget by the mid-1990s, but then decreased to about $5 \%$ in 2005 . This orientation towards responsive-mode funding has been confirmed by the new plan for the years 2008-2011.

\section{National trajectories}

Before we discuss our findings, we would like to point out that, in terms of the total amount of R\&D funding, research councils in all three countries have succeeded in increasing their share of total government allocations for R\&D (Figure 4). Comparing also research council project funding by purchasing power parities confirms the findings, as purchasing power in the three countries was at about the same level around 1980, while, during the 1980s, funding from the Norwegian councils was considerably more powerful before coming back to the level of the other two countries by the mid-1990s. Over the last few years, funding by the Austrian councils has gained in relative power. We conclude from this that over time the governments in the three countries to a varying degree have been willing to invest in their research councils, indicating some variations in the relationship between governments and councils. ${ }^{9}$ 


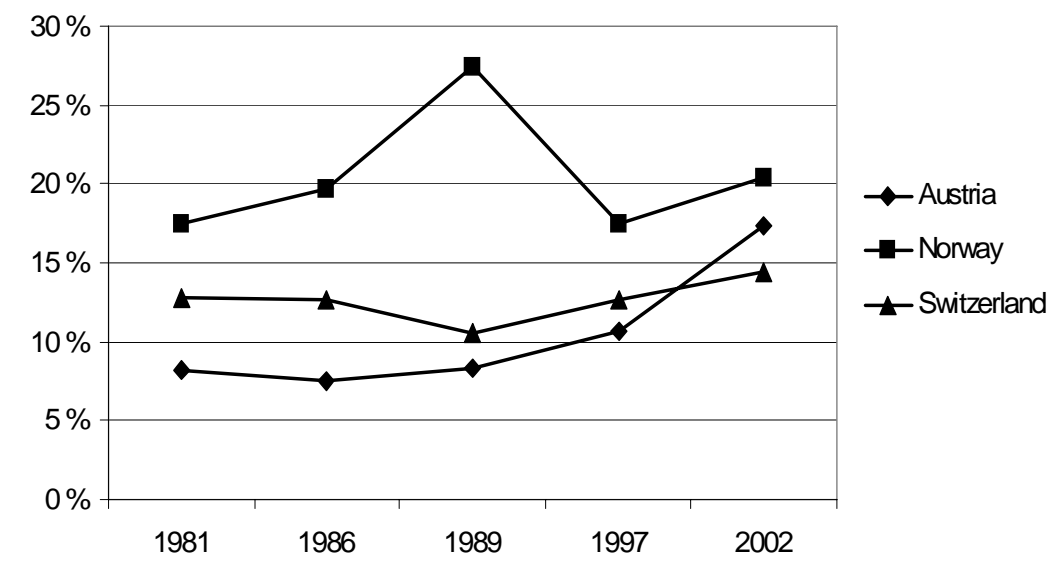

Figure 4. Share of project funding by research councils by GERD GOV

\section{Austria}

In the Austrian case, in our opinion, we find evidence of FFF and FWF being highly dependent on Government for their funding, but the internal governing structures and relationships with the beneficiaries has made them largely unresponsive to Government policies. In the end, this has provoked a total reorganising of the councils by Government, introducing a much stronger and direct Government influence on them from 2004 onwards. This development is open to several interpretations and possible explanations, but we point to some evidence to support our interpretation.

Governmental influence on budgets was prominent, since, during the 1970s and 1980s, they came almost $100 \%$ directly from Government; thus a dependency is to be expected. Even when budgets later came to be spread over more sources, to some extent they came indirectly from Government and Government direct allocations were reduced accordingly. Despite this dependency, the councils stuck to their original mission until the 1990s; the dedication to the FFF mission is demonstrated by the fact that, when Government budgets were reduced, the FFF shifted budgets forward to be able to meet its obligations towards the beneficiaries.

The legal mandate and mission of FFF provided an excellent basis for gaining wide responsibilities

\section{In Austria, the research councils seem to be highly dependent on Government for their funding, but the internal governing structures and relationships with beneficiaries has made them largely unresponsive to Government policies}

for innovation policy, but it restricted itself mainly to a narrow concept of bottom-up research-project funding by use of a traditional and well-established set of instruments acclaimed by the beneficiaries (Arnold, 2004). The lack of response first made Government initiate new agencies and instruments outside FFF. Later, Government reorganised the council system, introducing legislation allowing for direct influence on the programme portfolio by ministries, a strong ministerial representation on the boards (three of seven representative) and stronger links to the national strategies developed by RFT.

The FWF seems to have developed much in parallel, playing the role of a science-based council funding disciplinary projects in a responsive mode selected by quality criteria. The basic funding principles and internal organisation of FWF, however, have not altered dramatically with the reorganisation, and bottom-up research funding still accounts for the largest share of research-project funding. This might be a sign of unresponsiveness continuing.

The interesting question is how unresponsiveness to Government could prevail over such a long time, since the councils actually were totally dependent upon Government. Internally the councils were dominated by beneficiaries, since the Austrian model of governance delegates considerable power to organised societal interests, making it possible for the beneficiaries to remain in control of the councils.

Outside, responsibilities for research within Government was fragmented. The considerable change in Government policies and control of the councils after the 2004 evaluation might be considered as an example of a reorientation of the Austrian arrangements in the direction of a principal-agent model including greater Government steering capacity and an increased will to allocate public resources (compare with Figure 4).

\section{Norway}

In the Norwegian case, we find an example of councils being responsive to Government, but the sectorbased organisation of the science system and funding 
from several sources had fragmentation of the horizontal co-ordination, with rather unstable or fluctuating constellations as consequences. Quite close co-operation among councils, ministries and beneficiaries has created a situation in which these partners created 'collaborative responsiveness' within each sector. Councils were thus mostly able to balance the wishes of policy-makers and beneficiaries by using thematic instruments, but largely within the limited context of an economic sector.

Overall, we find it difficult to pinpoint definite patterns of development as both Government policies and council responses seem to have varied greatly. It is likely that the lack of co-ordination and unclear role of councils were part of the rationale behind the fundamental reorganisation (Skoie, 2000). The reorganisation probably came about not because councils were not responding to science policy, but rather, as the evidence below indicates, because the way the system was organised and steered asked for better co-ordination.

The mission-oriented councils had funding from several sources, but usually with one ministry as the main source (with some variations over time). Norwegian ministries also funded projects outside the councils and were consequently somewhat decoupling councils from Government. During the 1980s, this practice was to some extent reversed, but ministries partly opposed regulation and continued to initiate and fund projects of their own in addition to allocating funding to councils. The science-based NAVF had most of its funding from the football pool funds and was virtually independent of direct Government funding.

In total, these variations in funding might open the way for constellations of a more unstable kind with unclear dependencies. The composition of the boards also shifted over time; ministries took greater control of councils during the 1980s by increasing their representation and then decreasing it again after the establishment of NFR. These shifts in governmental influence probably reflect some ambiguity in the ministries regarding the usefulness of the councils and the need for direct influence.

Also the mission and allocation to beneficiaries varied among councils, and there were considerable variations over time. Agriculture (NLVF) and fisheries (NFFR) had a very restricted mission and to some extent had the role of political agencies, since they partly responded to priorities set outside the scientific realm as a result of problems caused by industrial restructuring. NTNF addressed broader industrial and technological development, but for a long time favoured its own research institutes.

NAVF exemplifies a different case because it operated basically as a science-based council with responsive-mode disciplinary funding schemes, though not only allocating funds to HEI. The mission and beneficiaries of the NFR cover all sectors and types of research, including the management of programmes initiated by policy-makers. Again, we interpret these variations as expressing some uncertainty within Government about the role of councils.

\section{Switzerland}

The development of SNF exemplifies a case in which the combination of a relatively weak state and an autonomous council tightly integrated with, and responsive to, a strong academic community have been able to defend this community's interests and thus also the SNF's own existence and strategies. By successfully manoeuvring its responses to the satisfaction of both policy-makers and beneficiaries, it has succeeded in keeping its organisation and mode of action virtually unchanged. The examination of SNF's share of funding above might indicate that the defence of a traditional role might have come at the price of its share of public resources.

The council has essentially been funded from one single Government source, potentially causing some dependence on this source. So SNF accepted in a period some change in its direction of being a strategic agency by including in its portfolio the national research programmes and national competence networks in research (NCCRs), where the Federal Government participates in the decision on research themes. We believe this model responds to two rationales: first, the wish of the public administration to gain some influence on project funding through the SNF; secondly, this joint management reduces the potential goal conflicts between these programmes and the general mission of the SNF, since the SNF is charged only with the evaluation of the scientific quality of the proposals, but not with the choice of the research themes.

This arrangement might indicate that the stability and autonomy presupposes a relatively close cooperation with Government in line with the Swiss consensus model of governance. On the other hand, the mission is definitely one of a science-based council operating mainly in a discipline-oriented manner and allocating funds to universities and, in line with this, it has been governed by a board of academics selected from the disciplines of highereducation institutions. After inclusion of thematic or mission-oriented programmes, the council has succeeded in transforming these into the standard portfolio of instruments, thus keeping to its mission and avoiding further governmental interference.

\section{Conclusions}

Our first research question concerned the responsiveness of the councils. From our material it is evident that research councils might be equally responsive to scientists and their institutions as to policy-makers, thus reducing the possibilities of implementing science policy. In our study, the Austrian case is the clearest example of councils de facto controlled by the beneficiaries, but also in the Norwegian 
and Swiss cases the councils have negotiated their responses to government and managed to find solutions, keeping their mission to the beneficiaries relatively unchanged despite policies towards the opposite.

On the other hand, in the Austrian case since 2004, we find evidence of councils being controlled directly by Government. In both the Austrian and Norwegian cases, we find examples of periods when ministries actually to some extent tried to avoid the use of councils, deliberately reducing the councils' possibilities of playing a role in science policy.

Our second question concerned the possible parallel or homogeneous development of councils and their relation to government in the three countries. We find some homogeneity in the way that in all countries there has been a development of policies towards greater use of thematic and innovative funding instruments. On the other hand, the case studies have demonstrated that research councils play distinctly different roles in the countries we have examined; their roles have developed and changed in disparate ways over the years, as well as government to a varying degree exercising control over the councils. This is an indication of research councils basically being strongly embedded in national policies and national research systems.

At a general level, our findings are illustrative of the limits of science policy. From government's point of view, a research council might ideally be considered a loyal tool in the implementation of policies, but in real life we are more likely to find a situation where loyalties are mediated and modified by the necessary involvement of science. Since a research council without the involvement of scientists probably will be even more counterproductive to the attainment of policy goals, the first alternative

\section{Notes}

1. Braun analyses the development of delegations as a direct relationship between government and scientists, and without the use of intermediaries. We also find the typology useful for understanding how the relationship between research council and scientists has developed since the councils in this case can be understood as the extension of government.

2. The study was undertaken by The European Network of Indicator Producers (ENIP) 2004 funded by the PRIME Network of Excellence. It includes Austria, France, Italy, Netherlands, Norway, Portugal, Spain and Switzerland (see Lepori et al, 2006a; 2006b; Lepori, 2006a; Dinges, 2006; Potì and Reale, 2006.

3. We are splitting project-funding instruments into three categories: academic; thematic; and innovation. This is far from simple since a classification can use different criteria based on funding objectives and allocation criteria, as well as the different types of research activity and beneficiary groups funded. See the cited papers for a detailed discussion.

4. The ERP Fund was established under the Marshall Plan for European reconstruction and provided support for technology transfer and innovation projects close to market that require significant investments in the form of loans and guarantees (see Jörg, 2004).

5. NORAS is omitted in analysis because if has been in existence only a short time (1987-1992)

6 . The FFG annual reports do not clearly distinguish between of policy-makers is to accept modifications to policy as an unavoidable transaction cost of policy implementation.

On the other hand, we have also seen that, if councils' responsiveness is not on a satisfactory level from policy-makers' point of view, they might opt for the exit alternative, that is, more or less abandon councils as an instrument for science policy and interact directly with scientists. A third alternative is the possibility of accomplishing science policies by exercising direct power over councils against the wishes of science but, as long as the fulfilment of the final goals of policies - creating new knowledge and innovation - has to be done by scientists, this is unlikely to be a useful policy for any long period of time.

From a theoretical point of view, our findings illustrate the need for multidimensional concepts for analysing the functioning of research councils. The much used principal-agent approach captures essential features of how councils work, but might be in danger of not capturing adequately the councils' complex embeddedness in the scientific and political system, or the factors affecting the responsiveness of councils. Introducing elements of organisation and system theory might thus supplement other approaches.

Our findings also illustrate that the political and scientific systems can be partly de-coupled, and that the science system is able to act independently of government despite its dependencies for funding. We cannot from our case study generalise that policy modifications are likely to be found in other areas of science policy where intermediaries are involved but, from a methodological point of view, future studies could benefit from taking into account the possibility of modifications by stakeholders' involvement.

various sources of funds, which makes analysis of this case difficult.

7. The Austrian Federal Economic Chamber WKÖ (15 members), the Austrian Federal Chamber of Labour AK (three members), the Austrian Federal Chamber of Agriculture (three members), and the Austrian Trade Union Federation ÖGB (three members).

8. For instance, in 2002, when FFF was asked to administer the BMVIT Impulse Programmes.

9. Factors such as the overall economic development and reallocations between sectors can also influence this.

\section{References}

Arnold, E 2004. Evaluation of the Austrian Industrial Research Promotion Fund (FFF) and the Austrian Science Fund (FWF). Synthesis report. Wien: E Arnold.

Arnold, E, S Kuhlmann and B van der Meulen 2001. A singular council. Evaluation of the Research Council of Norway. Brighton: Technopolis.

Braun, D 1998. The role of funding agencies in the cognitive development of science. Research Policy, 27(8), 807.

Braun, D 2003. Lasting tensions in research policy-making - a delegation problem. Science and Public Policy, 30(5), October, 309-321.

Braun, D and M Benninghoff 2003. Policy learning in Swiss 
research policy - the case of the National Centres of Competence in Research. Research Policy, 32(10), 1849-1863.

Braun, D and D H Guston 2003. Principal-agent theory and research policy: an introduction. Science and Public Policy, 30(5), October, 302-308.

Caswill, C 2003. Principals, agents and contracts. Science and Public Policy, 30(5), October, 337-346.

Dinges, M 2006. Project funding report: Austria. Wien: Joanneum Research, Institute of Technology and Regional Policy.

FTFG, Bundesgesetz zur Förderung der Forschung und Technologieentwicklung (Forschungs- und Technologieförderungsgesetz, FTFG), 2006. StF: BGBI. Nr 434/1982 idf $11 / 2006$. Wien.

Geuna, A 2001. The changing rationale for European university research funding: are there negative unintended consequences? Journal of Economic Issues, 35(3), 607.

Geuna, A and B R Martin 2003. University research evaluation and funding: an international comparison. Minerva, 41(4), 277-304.

Gulbrandsen, J M 2005. Tensions in the research councilresearch community relationship. Science and Public Policy, 32(3), June, 199-209.

Guston, D H 1996. Principal-agent theory and the structure of science policy. Science and Public Policy, 23(4), August, 229-240.

Jörg, L 2004. Policy profile Austria. Input Paper for the OECD NIS MONIT Network. Wien: Technopolis $\mathrm{GmbH}$. Available at $<$ http://www.tip.ac.at/(de)/publications/st_2004_policy_profile\$. pdf>, last accessed 30 August 2007.

Laudel, G 2006. The 'quality myth': promoting and hindering conditions for acquiring research funds. Higher Education, 52(3), 375.

Lepori B 2005. Project funding. Switzerland. Country report. Paris: European Network of Indicators Producers.

Lepori B 2006a. Public research funding and research policy: a long-term analysis for the Swiss case. Science and Public Policy, 33(3), April, 205-216.

Lepori B 2006b. Methodologies for analysis of research funding and expenditure: from input to positioning indicators. Research Evaluation, 15(2), 133-143.

Lepori, B, M Dinges, $\mathrm{P}$ van der Besselaar, R Mampuis, B Potì, E Reale, S Slipersæter, J Theves and B van der Meulen 2006a. Convergence versus national specificities in research policies. An empirical study on public project funding. Paper presented at the conference Indicators on Science, Technology and Innovation. History and New Perspectives. Lugano, 15-17 November.
Lepori, B, M Dinges, R Mamphuis, B Potì, E Real, S Slipersæter, J Theves, B van der Meulen 2006b. Indicators for comparative analysis of public project funding. Concepts, implementation and evaluation. Paper presented at the 9th International Conference on Science and Technology Indicators, Leuven, 7-9 September.

Lepori, B, P van den Besselaar, M Dinges, B van der Meulen, B Potì, E Reale, S Slipersæter and J Thèves 2007a. Indicators for comparative analysis of public project funding. Concepts, implementation and evaluation. Research Evaluation, 17(1), March, forthcoming.

Lepori B, P van den Besselaar, M Dinges, B van der Meulen, B Potì, E Reale, S Slipersæter and J Thèves 2007b. Comparing the evolution of national research policies: what patterns of change? Science and Public Policy, 34(6), July, 372-388.

Oliver, C 1991. Strategic responses to institutional processes. The Academy of Management Review, 16(1), 145-179.

Petersen, $T$ 1993. The economics of organization: the principal-agent relationship. Acta Sociologica, 36(3), 277-293.

Potì, B and E Reale 2005. Changing patterns in public allocation for R\&D: composition and evolution of Government project funding in Italy. Paper presented at the S\&T indicators for policy analysis: needs, status and new developments conference, Lisbon, 21-23 September.

Potì, B and E Reale 2006. Project funding report: Italy. Rome: CNR CERIS section on institutions and research policies.

Scott, W R 1992. Organizations. Rational, Natural, and Open Systems. Englewood Cliffs NJ: Prentice-Hall.

Skoie, H 2000. Diversity and identity: the merger of five research councils in Norway. Science and Public Policy, 27(2), April, 83-96.

Skoie, H 2005. Norsk forskningspolitikk i etterkrigstiden. Oslo: Cappelen.

Statskonsult 1994. Styresystemtet i Norges forskningsråd: Kartlegging og forbedringsforslag. Oslo: Statskonsult.

Thompson, P and D McHugh 1995. Work Organisations. A Critical Introduction. London: Macmillan Press.

van der Meulen, B 1998. Science policies as principal-agent games - institutionalization and path dependency in the relation between government and science. Research Policy, 27(4), 397.

van der Meulen, B 2003. New roles and strategies of a research council: intermediation of the principal-agent relationship. Science and Public Policy, 30(5), October, 323-336.

van der Meulen, B and A Rip 1998. Mediation in the Dutch science system. Research Policy, 27(8), 757. 